\title{
Introduction
}

\section{Jesuit Missionary Perspectives and Strategies} Across the Early Modern Globe

\author{
Bronwen Catherine McShea \\ Guest Editor \\ ACLS New Faculty Fellow and Lecturer, Department of History, \\ Columbia University \\ bcm2140@columbia.edu
}

Jesuit missionaries who cultivated Catholic worship and belief across the early modern globe are increasingly a focus of interdisciplinary scholarly research. Due, in part, to spreading interest in Jesuit history per se far beyond the older, "in house" scholarship of the Society of Jesus, attention to Jesuit missionaries reflects, as well, increasing recognition across the humanities of the role of religion generally in shaping the modern world. ${ }^{1}$ Over the past several decades, a number of innovative analyses of Jesuit missionary writings and activities have appeared from scholars not focused primarily on missionaries or on Christianity as such. ${ }^{2}$ At the same time, much new work focused on Jesuits and

* Bronwen Catherine McShea has been a Visiting Scholar at Harvard University's Center for the Study of World Religions (CSWR) and a Postdoctoral Research Fellow of the Leibniz Institute of European History (IEG) in Mainz, Germany. She received her Ph.D. in History from Yale University and an M.T.S. in the History of Christianity from Harvard Divinity School.

1 See for example Owen White and J.P. Daughton, eds., In God's Empire: French Missionaries and the Modern World (Oxford: Oxford University Press, 2012); Parna Sangupta, Pedagogy for Religion: Missionary Education and the Fashioning of Hindus and Muslims in Bengal (Berkeley: University of California Press, 2011); Rebekka Habermas, "Mission im 19. JahrhundertGlobale Netze des Religiösen," Historische Zeitschrift 287 (2008): 629-679; Andrew Porter, Religion Versus Empire? British Protestant Missionaries and Overseas Expansion, 1700-1914 (Manchester: Manchester University Press, 2004).

2 A small sampling includes Sara E. Melzer, Colonizer or Colonized: The Hidden Stories of Early Modern French Culture (Philadelphia: University of Pennsylvania Press, 2012); Alida C. Metcalf, Go-Betweens and the Colonization of Brazil: 1500-1600 (Austin: University of Texas Press, 2005); David A. Brading, The First America: The Spanish Monarchy, Creole Patriots, and the Liberal State, 1492-1867 (Cambridge: Cambridge University Press, 1991); James Axtell, The Invasion Within: The Contest of Cultures in Colonial North America (New York: Oxford University Press, 1985). 


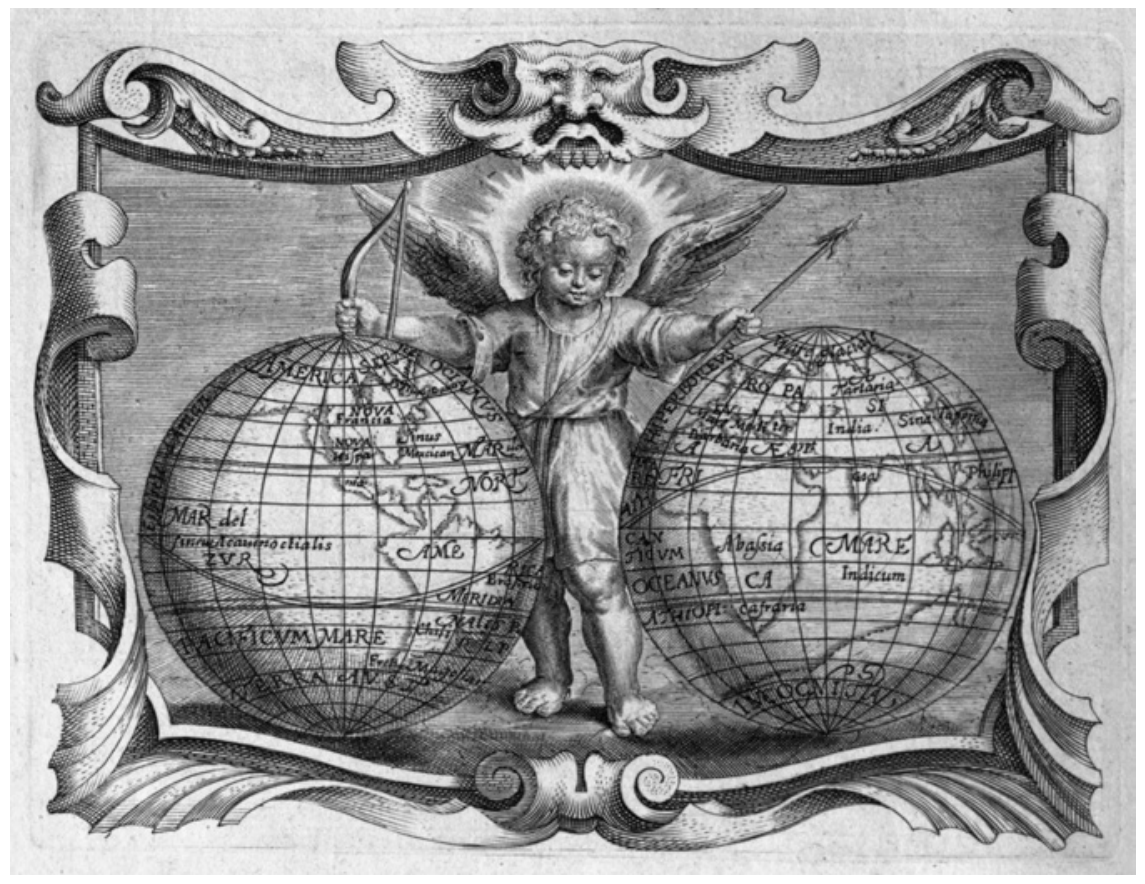

An engraving from Imago primi sæculi Societatis Iesu (Antwerp: Moretus, 1640) referring to the Jesuit missionary enterprise. The caption reads: Unus non sufficit orbis [One world is not enough]. Courtesy of the John J. Burns Library at Boston College (http://www .bc.edu/libraries/collections/burns.html).

their missions arises from concentrated interest in early modern Catholicism as a global phenomenon, often neglected in older historiographical conversations on the European Counter-Reformation. ${ }^{3}$

The cross-pollination newly possible between Jesuit studies and other research fields permits scholars to examine early modern Catholicism in relation to world cultures from new vantage points. In this issue, seven scholars

3 Markus Friedrich, Der lange Arm Roms? Globale Verwaltung und Kommunikation im Jesuitenorden, 1540-1773 (Frankfurt: Campus Verlag, 2011); Luke Clossey, Salvation and Globalization in the Early Jesuit Missions (Cambridge: Cambridge University Press, 2008); Liam Matthew Brockey, Journey to the East: The Jesuit Mission to China, 1597-1724 (Cambridge: Harvard University Press, 2007); Dauril Alden, The Making of an Enterprise: The Society of Jesus in Portugal, Its Empire, and Beyond, 1540-175o (Stanford: Stanford University Press, 1996). For a fuller discussion of recent historiography on Jesuit missions across the globe, see Ronnie Po-chia Hsia, "Jesuit Foreign Missions: A Historiographical Essay," Journal of Jesuit Studies 1/1 (2014): 47-65. 
working from historical, anthropological, theological, and linguistic standpoints address two of these - the questions of how European Catholics historically perceived different world cultures, and how they attempted and sometimes succeeded in cultivating Christianity among them-by following Jesuits employed in sixteenth- and seventeenth-century West Central Africa, the Ottoman Empire, Brazil and the Andes, China, North America, and throughout Europe itself. These scholars draw from an array of printed and archival sources-some well-known but bearing new fruit in Jesuit studies, such as José de Acosta's Historia natural y moral de las Indias (1590), and others less familiar such as the Kimbundu Catechism developed in the 1620 s by Jesuits in Angola.

The first article by Ana Carolina Hosne adds to a growing body of work on Jesuits who studied world cultures not only to translate Catholic doctrines and ritual practices into new idioms and contexts, but also out of humanistic and scientific curiosity. ${ }^{4}$ Such curiosity was borne of the shock of cultural encounter itself as well as the spirit of Renaissance Humanism and the early scientific revolution, which their Jesuit confreres did much to advance in Europe. Contrasting Jesuit perspectives on Andean "writing systems" and on Chinese intellectual culture as a "world of letters" capable of sophisticated intellectual exchanges with Europe, Hosne sheds new light on missionary mentalities in both contexts while addressing how and why different cultures engaged by Jesuits inspired different degrees of curiosity and respect among them.

Emanuele Colombo also responds to growing interest in comparisons of different Jesuit mission across geographies and cultures. ${ }^{5}$ Comparing Jesuit views of, and strategies among, Muslim societies in both Spain and Naples, he expands on a body of scholarship on missions within Europe itself which traditionally were neglected in older institutional Jesuit histories in favor of overseas missions, especially in Asia and the Americas. ${ }^{6}$ Colombo offers new insight into Jesuit views of Islam, missionary styles of preaching and uses of theater

4 Andrés I. Prieto, Missionary Scientists in Spanish South America, 1570-1810 (Nashville: Vanderbilt University Press, 2011); Florence C. Hsia, Sojourners in a Strange Land:Jesuits and Their Scientific Missions in Late Imperial China (Chicago: University of Chicago Press, 2009); Gauvin Alexander Bailey, Art on the Jesuit Missions in Asia and Latin America, 1542-1773 (Toronto: University of Toronto Press, 2001).

5 Takao Abé, The Jesuit Mission to New France: A New Interpretation in the Light of the Earlier Jesuit Experience in Japan (Leiden: Brill, 2011); Charlotte de Castelnau-L'Estoile et al., eds., Missions d'évangelisation et circulations des savoirs: XVI-XVIIIe siècle (Madrid: La Casa de Valázquez, 2011); Clossey, Salvation and Globalization; Alden, The Making of an Enterprise.

6 See especially Paolo Broggio, Evangelizzare il Mondo: Le missioni della Compagnia de Gesù tra Europa e America (secoli XVI-XVII) (Rome: Caracci, 2004); Dominique Deslandres, Croire et Faire Croire: Les missions françaises au XVIIe siècle (1600-1650) (Paris: Fayard, 2003). 
and other displays, and the social contexts of missions that affected Muslim galley slaves, farmers, and merchants in different southern European contexts.

Elizabeth Ellis-Marino takes it for granted, too-as could not be done a decade or so ago - that the study of Jesuit missions as a "global" phenomenon should include evangelization enterprises unfolding within the geographical boundaries of old European Christendom. Considering Jesuit efforts to Catholicize the Protestant territory of Paderborn in northwestern Germany alongside Jesuit catechetical efforts in the more solidly Catholic region of Ingolstadt, she considers the role of school drama as a means of persuading the larger community, which had recently resisted the local bishop's CounterReformation policies through armed rebellion, to reconcile with and remain committed to the Roman church.

Turning to missions in Portuguese colonial contexts, Anne McGinness and John Thornton consider developments in Jesuits' catechetical strategies in Latin America and West Africa, respectively, as shaped in response to political and cultural circumstances. McGinness examines the career of José de Anchieta who preached among Tupi speakers in colonial Brazil during and after the Indian wars around Rio de Janeiro (1558-1562) which involved both the Portuguese and the French. Known for the bilingual catechisms which he wrote and translated in his early years as a missionary, Anchieta later turned to theater as a means of instructing indigenous communities formed in the wake of social displacements resulting from the wars. McGinness considers whether and how Anchieta's Tupi grammars, catechism, and earlier experiences in Brazil grounded these later catechetical efforts that joined Tupi rhetoric and imagery, in dramatized forms, to the missionary's Catholic preaching.

John Thornton examines strategies adopted by Jesuits in the Portuguese colony of Angola in the sixteenth and seventeenth centuries, employing the catechism in the Kimbundu language, developed in the 1620 s, as an entry point into the mission. The Jesuits in Angola preached to already-baptized persons who had submitted to the Portuguese Crown following the conquest of 1575 , and they also drew from the experiences of Jesuits in Kongo to the north-not under Portuguese rule-who worked instead under the auspices of local Kongolese religious and political leaders. More responsible for the content of catechesis in Angola than were the Jesuits in Kongo, the Jesuits in Angola recruited lay Kongolese teachers and native Kimbundu speakers to assist their labors. Highlighting West Central African religious terms and concepts that are deeply embedded in the catechism, Thornton underscores the Jesuits' efforts to reconcile Christianity with traditional Angolan religious culture.

Political context is especially crucial to Adina Ruiu's discussion of the understudied French missions in the Ottoman Empire in the early seventeenth 
century. Employing archival material that has been neglected in the study of French missionary activity in the era, such as communiqués between missionaries and the French ambassadors in Istanbul, Ruiu tracks ways missions were shaped through Jesuits' negotiations-sometimes contentious-with European governmental and ecclesiastical leaders. In this, she questions whether the missions in the Ottoman Empire were the product of a specifically Jesuit vision of mission, suggesting rather that they were, in large part, the fruit of ongoing negotiations between Jesuits and other religious and political elites about the purpose and proper structure of their new missions.

Finally, focusing on a more well-known group of French Jesuits who nevertheless continue to attract the attention of anthropologists, historians, and other scholars, Muriel Clair highlights a little known chapter in the seventeenth-century mission to New France. In their early attempts to evangelize nomadic Algonquian-speaking populations north of Quebec, the Jesuits relied greatly on indigenous proselytes themselves to mediate between postTridentine Roman Catholicism and the spirituality of the local populations. Clair is also attentive to ways a specific mission, and its developing strategies of evangelization, was significantly the product of non-Jesuits collaborating with the mission fathers. She also considers the dynamics of metropolitan, French views of the mission, and ways the Jesuits negotiated between two very different religious cultures on both sides of the Atlantic Ocean. At the same time, she casts into relief mission strategies that embraced particular aspects of Algoquian material culture and understandings of temporality, arguing for a historic transition to a new Jesuit recognition of distinctively Native American expressions of Christianity.

The studies in this issue were selected to represent a wide variety of world cultures engaged by the early modern Jesuits as well as a diversity of historically grounded analytical approaches which are driving the field of Jesuit studies. While a number of key geographical regions penetrated by early modern Jesuit missionaries, such as Japan, India, and Eastern Europe, have not been included in this issue, the articles that follow convey a balanced sense of the truly world-wide scope of the early Jesuit enterprise as well as the great diversity of circumstances - both local and metropolitan — which both informed and limited Catholic evangelization across the early modern globe. While acknowledging with Luke Clossey that the world-wide Jesuit enterprise was unified in purpose - to save as many souls from sin, Satan, and perdition as possible, by means of preaching and dispensing the Catholic sacramentsthis issue also underscores, with Ronnie Po-chia Hsia, that there is much we still do not know about the contours and experimental nature of many early Jesuit efforts to understand, and to evangelize, world cultures that were very 
new to them. ${ }^{7}$ Further inquiry into the circumstantial particularity of the early missions, many of which resulted from Jesuit negotiations and collaboration with both local and metropolitan elites, including lay persons, is crucial for better illuminating not only the more unifying structures and missionary principles of the Society of Jesus, but also what it was about Catholicism per se which gained traction in the diverse world cultures in which it took hold.

7 Clossey, Salvation and Globalization, 240-241; Hsia, "Jesuit Foreign Missions: A Historiographical Essay," 65. 